\title{
Evidence that collaborative action between local health departments and nonprofit hospitals helps foster healthy behaviors in communities: a multilevel study
}

Geri Rosen Cramer ${ }^{1}$, Gary J. Young ${ }^{2}$, Simone Singh ${ }^{3}$, Jean McGuire ${ }^{4}$ and Daniel Kim ${ }^{5^{*}}$

\begin{abstract}
Background: The Patient Protection and Affordable Care Act of 2010 (ACA) encouraged nonprofit hospitals to collaborate with local public health experts in the conduct of community health needs assessments (CHNAs) for the larger goal of improving community health. Yet, little is known about whether collaborations between local health departments and hospitals may be beneficial to community health. In this study, we investigated whether individuals residing in communities with stronger collaboration between nonprofit hospitals and local public health departments (LHDs) reported healthier behaviors. We further explored whether social capital acts as a moderating factor of these relationships.
\end{abstract}

Methods: We used multilevel cross-sectional models, controlling for both individual and community-level factors to explore LHD-hospital collaboration (measured in the National Association of County and City Health Officials (NACC HO) Forces of Change Survey), in relation to individual-level health behaviors in 56,826 adults living in 32 metropolitan and micropolitan statistical areas, captured through the 2015 Behavioral Risk Factor Surveillance System (BRFSS) SMART dataset. Nine health behaviors were examined including vigorous exercise, eating fruits and vegetables, smoking and binge drinking. Social capital, measured using an index developed by the Northeast Regional Center for Rural Development, was also explored as an effect modifier of these relationships.

Results: Stronger collaboration between nonprofit hospitals and LHDs was associated with not smoking (odds ratio, OR 1.32, 95\% Cl 1.11 to 1.58), eating vegetables daily (OR 1.29; 95\% Cl 1.06 to 1.57), and vigorous exercise (OR $1.17 ; 95 \% \mathrm{Cl} 1.05$ to 1.30). The presence of higher social capital also strengthened the relationships between LHDhospital collaborations and wearing a seatbelt $(p$ for interaction $=0.01)$ and general exercise $(p$ for interaction $=$ 0.03).

* Correspondence: d.kim@northeastern.edu

${ }^{5}$ Bouvé College of Health Sciences and the School of Public Policy and

Urban Affairs, Northeastern University, Boston, MA, USA

Full list of author information is available at the end of the article

(c) The Author(s). 2021 Open Access This article is licensed under a Creative Commons Attribution 4.0 International License, which permits use, sharing, adaptation, distribution and reproduction in any medium or format, as long as you give appropriate credit to the original author(s) and the source, provide a link to the Creative Commons licence, and indicate if changes were made. The images or other third party material in this article are included in the article's Creative Commons licence, unless indicated otherwise in a credit line to the material. If material is not included in the article's Creative Commons licence and your intended use is not permitted by statutory regulation or exceeds the permitted use, you will need to obtain permission directly from the copyright holder. To view a copy of this licence, visit http://creativecommons.org/licenses/by/4.0/. The Creative Commons Public Domain Dedication waiver (http://creativecommons.org/publicdomain/zero/1.0/) applies to the data made available in this article, unless otherwise stated in a credit line to the data. 
(Continued from previous page)

Conclusions: Stronger collaboration between nonprofit hospitals and LHDs was positively associated with healthier individual-level behaviors. Social capital may also play a moderating role in improving individual and population health.

Keywords: Collaboration, Population health, Local health department, Nonprofit hospital, Social capital, Health behaviors

\section{Background}

In 2014, the United States ranked last among highincome countries on measures of mortality and life expectancy while health expenditures per person were more than double the highest-ranking country $[1,2]$. Within the US, significant health disparities exist within and across populations and regions [3]. The pioneering work of the Robert Wood Johnson Foundation's "Culture of Health Action Framework" and the Institute for Healthcare Improvement (IHI)'s "Triple Aim," have proposed that health is a function of community assets and socioeconomic circumstances $[4,5]$. Cross-sector partnerships between local public health departments and healthcare providers are a potentially important resource for improving community health and wellbeing.

However, a long-standing chasm has existed between the public health and healthcare delivery sectors $[6,7]$. In general, local health departments (LHDs) have the mission to promote community health through programs aimed at disease prevention and emergency preparedness. Meanwhile, healthcare providers focus on patient-level treatment for acute and chronic health conditions. Among healthcare providers, hospitals are a particularly important community asset as they possess knowledge, data, and human capital resources that are relevant for improving community health [8]. Although over half of US hospitals are nonprofit, tax-exempt entities and therefore carry societal and governmental expectations to provide community benefits, these hospitals have typically sought to meet this expectation by providing charity care to the poor or investing in health education and research activities [9]. These efforts address important needs but do little to directly improve community health [9]. Collaboration between LHDs and hospitals may be impeded by differences in mission, language and training of those in leadership positions [10].

At the same time, empirical research has explored the potential benefits that can be gained from greater levels of collaboration between LHDs and hospitals. One of the few relevant studies found that when hospitals and LHDs do collaborate on community health needs assessments, the results are more comprehensive and detailed than when either entity (LHD and hospital) conducted an assessment independently [11]. In addition, an ecological study conducted by Mays et al. showed that greater collaboration among various stakeholders was associated with lower county-level mortality rates [12]. Yet, a significant knowledge gap exists in that none of these studies have implemented a multilevel study design to directly test whether collaboration between LHDs and hospitals is associated with health behaviors when measured at the individual-level.

\section{Conceptual framework}

Although there are many relevant frameworks in the public health, sociology and economics literature that address community health and welfare, we adapt a framework created by the Bay Area Regional Health Inequities Initiative (BARHII, modified framework in Fig. 1) [13].

The BARHII Framework for Reducing Health Inequities has become a useful tool for LHDs seeking to better address social determinants [13]. This framework is particularly suitable for our work in that it recognizes the importance of strategic partnerships between institutions and articulates that individual health behaviors are on the path to individual disease and mortality.

One area of interest not explicitly identified in the BAHRII Framework is the concept of social capital. In a community context, social capital has been defined as the "source of the ability to identify problems and needs, achieve a workable consensus on goals and priorities, and work in partnership with others to achieve goals." $[14,15]$ Putnam, in his seminal work "Bowling Alone", described community-level social capital as being a "public good" whereby efforts from collective action may benefit the population at large [16].

In this study, we sought to address two key research questions using a multilevel study design: (1) are individuals residing in communities with long-standing LHDhospital collaborative action on community-wide health promotion more likely to report healthier behaviors than individuals residing in communities with less collaborative action?; and (2) does the level of social capital of a community modify the relationships between longstanding LHD-hospital collaborative action and health behaviors of individuals?

We hypothesized that individuals residing in communities with long-standing collaborative action would report healthier behaviors. We believe that LHDs and 


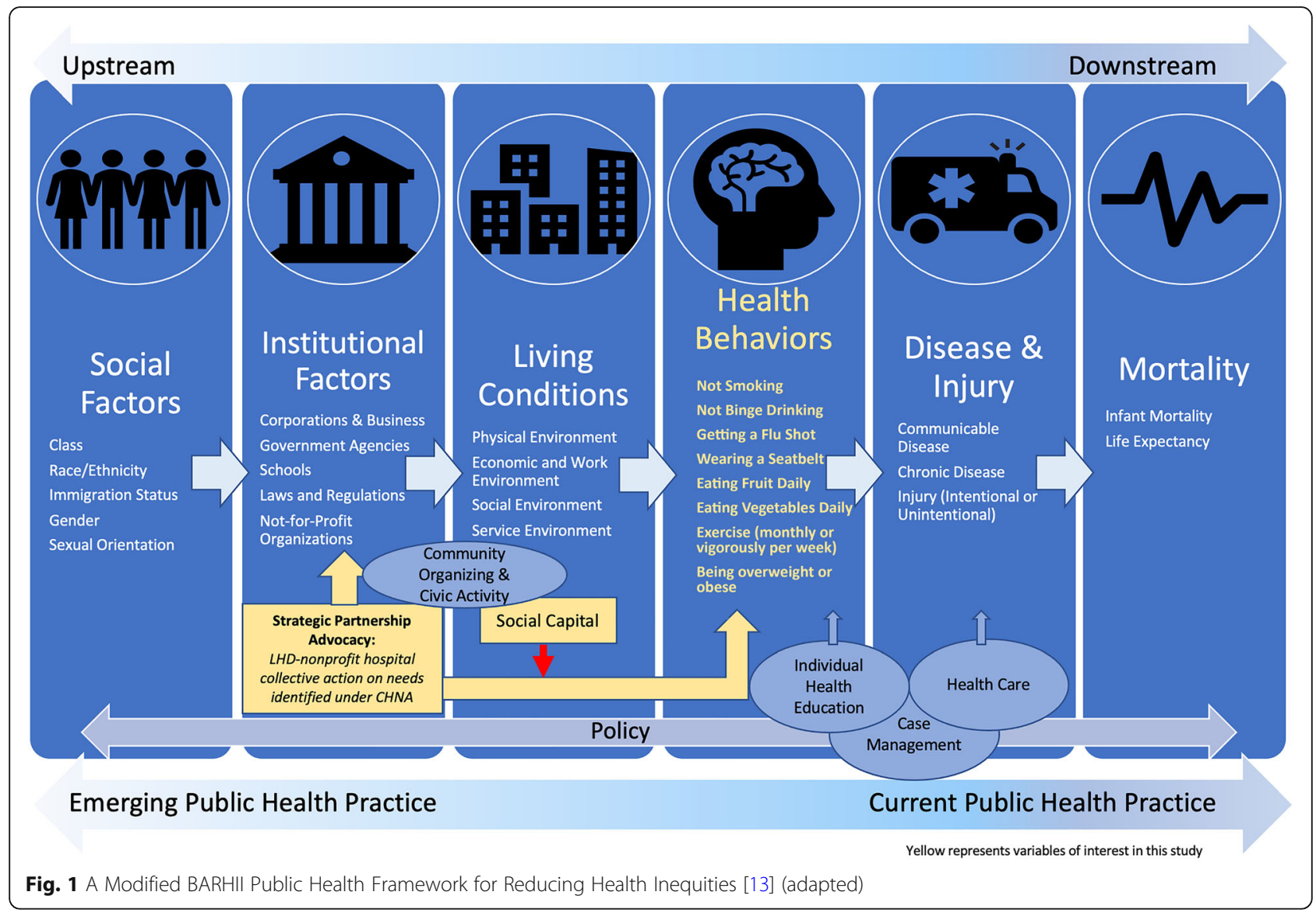

nonprofit hospitals that engage in long-standing collaborative action benefit from the synergies that have been observed through research on collaboration outside of the health context [17]. We also hypothesized that higher levels of community social capital could serve as a facilitator in these efforts. That is, social capital may act as a catalyst for such collaborative action to be effective.

\section{Methods}

\section{Study population}

Our study population consisted of 56,826 adults living in 32 metropolitan and micropolitan statistical areas (MMSA) in the United States. Geographies were selected for which we had individual-level responses and a single LHD that reported the presence of at least one nonprofit hospital within its jurisdiction.

\section{Outcomes}

Information on individual-level health behaviors came from the 2015 Behavioral Risk Factor Surveillance Survey (BRFSS) SMART dataset. The 2015 BRFSS SMART dataset is a sub-sample of the 2015 state BRFSS surveys based on geographies defined as metropolitan statistical areas, micropolitan statistical areas, and metropolitan divisions (collectively called MMSAs) made publicly available to researchers. The 2015 BRFSS Smart dataset included 132 MMSAs where at least 500 BRFSS surveys were collected [18].

Individual health behaviors selected for this study were those identified by the Centers for Disease Control and Prevention (CDC) as "Winnable Battles". Winnable Battles are health outcomes for which the CDC believes that public health can make significant progress in a relatively short time frame (i.e., within one to 4 years), have a large-scale public impact, and have evidenced-based interventions readily available for ease of implementation. From the "Winnable Battles" list, we included the following modifiable behaviors/conditions into our analysis: smoking, wearing a seatbelt, binge drinking, eating vegetables daily, eating fruit daily, general exercise in a month, vigorous exercise $(300 \mathrm{~min})$ in a week and being overweight or obese (based on self-reported height and weight). Additionally, while not designated by the CDC as a "Winnable Battle", flu vaccinations are also an important measure of community health where LHDs and nonprofit hospitals may collaborate and was thus included in our analysis. While we did not have access to specific collaborative action strategies, many of the included measures are commonly identified in community 
health needs assessments (CHNAs) as being health needs in the community (healthy eating, physical activity, smoking, etc.) $[19,20]$.

In addition to studying the impact of LHD-hospital collaboration on specific individual health behaviors, we also conducted analyses using two index measures of the health behaviors. We created one index for risky behaviors and another for healthy lifestyle behaviors (healthy eating and exercise).

The risky behaviors index included wearing a seatbelt, not smoking, not binge drinking and getting a flu shot. For each individual respondent, we assigned a score for this index based on the number of specific behaviors that the individual reported undertaking (or in the case of smoking and binge drinking reported not undertaking). Thus, if an individual did not report undertaking any of these behaviors, we assigned a score of zero. If an individual reported all of the behaviors, we assigned a score of four. To create the healthy lifestyle index, we combined the specific behaviors of eating vegetable(s) daily, eating fruit daily and vigorously exercising. We found a high correlation between general exercise and vigorous exercise and felt the latter was more representative of a healthy lifestyle, so we included that variable only. For this index, we also assigned a score to each individual respondent based on the number of behaviors that reportedly were undertaken. Thus, the healthy lifestyle index ranged from zero (if an individual did not report any of the variables) to three (if an individual reported eating fruit, vegetables and vigorously exercising). Index variables were analyzed as continuous outcomes.

\section{Predictor variables}

The data for assessing the level of collaboration between LHDs and nonprofit hospitals came from the 2015 Forces of Change Survey administered by the National Association of County and City Health Officials (NACC $\mathrm{HO}$ ). This survey was developed to measure the impacts of economic forces on the budget, staff, and programs of LHDs. The survey was administered to a subset of the nearly 3000 LHDs across the country using stratified random sampling (on state and size of population in the LHD jurisdiction) [21]. Nine hundred and forty-eight (948) LHDs were randomly selected, of which 690 LHDs participated (73\% response rate). Approximately $77 \%$ of the included LHDs reported having at least one nonprofit hospital in their jurisdiction $(n=519)$.

We used each LHD's response to a single question as a proxy for whether it had a long-standing collaboration with nonprofit hospitals in the community for which the LHD was responsible [22, 23]. The survey question asks "Is your LHD included in any nonprofit hospital's implementation plan for the community health needs assessment (CHNA)?" Response options included: no collaboration, participating in the development of a hospital implementation plan, listed as a partner in a hospital implementation plan, conducting an activity together in a hospital implementation plan, and using the same implementation plan as the hospital. Because we were interested in identifying established collaborations between LHDs and hospitals within local communities, we created a binary variable indicating "longstanding collaboration" for those LHDs that reported conducting an activity together or using the same implementation plan as the nonprofit hospital in their community. Although the survey question did not specify a defined time period for reported LHD-hospital collaboration, such CHNA implementation efforts typically entail multiple years of activity. Accordingly, we interpreted LHD responses indicating a joint effort for implementing community health needs assessments to be reflective of relatively long-standing relationships (or lack thereof) between an LHD and one or more nonprofit hospitals in a community. While this variable lacked granularity in terms of the nature, strength, and scale of LHD-hospital collaboration (e.g., the content of implementation plans was not known), previous research suggests that any level of meaningful, ongoing collaboration between these two sectors within the same community is uncommon [24]. Thus, we constructed this variable to measure if such collaboration is associated with positive individual-level health outcomes.

\section{Social capital as a potential effect modifier}

To assess whether community social capital moderated the relationship between LHD-hospital collaboration and individual-level health behavior, we used the 2014 Northeast Regional Center for Rural Development (NRCRD) social capital index as developed by Rupasingha et al. (2006) [25]. This social capital index was created using principal component analysis based on four factors: the percentage of voters who voted in presidential elections, the response rate to the Census Bureau's decennial census, the number of non-profit organizations, and the number of social organizations and associations [25]. For social capital, the geographic unit was the county in which the LHD was located. While this was not the unit for the primary analysis, a metropolitan or micropolitan statistical area (MMSA) is defined as a region that consists of a city and surrounding communities that are linked by social and economic factors, as established by the U.S. Office of Management and Budget (OMB) [18]. Thus, social capital at the countylevel was deemed an adequate measure for this analysis.

\section{Covariates}

In all models, we controlled for factors at the individual level (age, marital status, race, education, household 
income, and health insurance status from the BRFSS, all as categorical variables except for age) and the community-level (median household income and percent black), derived from the 2010 U.S. Census and Area Resource File [26-28]. Individual survey responses were linked to community-level characteristics from the NRCRD social capital index and NACCHO Profile Survey (2013). We included a variable indicating whether an LHD had more than the average number of full-time equivalents (FTEs) from all LHDs responding to the 2013 NACCHO Profile survey. FTEs relate to a LHD's resource availability that may affect collaborative action as well as health outcomes [29]. We also controlled for the presence/absence of a local board of health, which has been shown to influence collaboration between nonprofit hospitals and LHDs [23]. Finally, we controlled for whether the state had expanded Medicaid as of 2015.

\section{Statistical analysis}

Due to missing data for two covariates-whether the individual identified as being insured and the individual's income (35 and 18\%, respectively)-we implemented a multiple imputation approach using proc. mi, SAS version 9.4 [30]. To assess whether there was residual confounding in missing observations for the health insurance variable, we conducted a sensitivity analysis that excluded the health insurance variable from our models that analyzed the two health behavior indices. Missing data on the outcomes of interest (ranging from $4.3 \%$ for not smoking to $13.2 \%$ for vigorous exercise) was cause for excluding the individual from the analysis.

To examine the relationship between LHD-hospital collaboration and an individual's reported health behavior, we estimated hierarchical generalized linear models using proc. glimmix [31]. We generalized the individual-level logistic regression model for binary and continuous outcomes and incorporated the aforementioned community- and individuallevel covariates. All models incorporated random intercepts to capture the variation among communities and to adjust the estimates for the lack of independence and clustering of individual responses within each community. Hypothesis testing was two-sided with a type 1 error rate of 0.05 .

\section{Results}

As noted, after data linkages our sample comprised 56, 826 respondents representing 32 communities across 25 states. Geographies were excluded if there was no data from both the Forces of Change survey or BRFSS Smart and if the MMSA (from the BRFSS Smart) represented more than one LHD. Table 1 compares descriptive statistics between respondents from these 32 communities and those from excluded communities. The two groups were largely comparable except for race/ethnicity, whereby included communities' members were more likely to self-identify as white ( $83.3 \%$ vs $79.6 \%)$.

Within our sample, approximately $14 \%$ of the population reported smoking, $12 \%$ reported binge drinking, $11 \%$ reported not wearing a seatbelt and $51 \%$ reported not getting a flu shot. Despite most of the individuals reporting that they ate fruits and vegetables daily (62 and $80 \%$ respectively), $65 \%$ of respondents identified as being overweight or obese. Seventy-five percent (75\%) of individuals reported that they performed some type of exercise monthly but only $38 \%$ reported vigorously exercising weekly.

Variation also existed for the key independent variable, the level of LHD-hospital collaboration. Approximately $22 \%$ of the communities in our sample reported longstanding collaboration between the LHD and one or more hospitals in its community (7 of 32 LHDs). Thus, $78 \%$ of the communities in our sample reported relatively little or no LHD-hospital collaboration. Those LHDs answering "I don't know" were assumed to have no collaboration with nonprofit hospitals, an assumption previously used in the peer-reviewed literature [23]. Thus, in line with previous studies, long-standing collaboration between LHDs and hospitals appeared to be uncommon and thus, the binary variable for LHD-hospital collaboration included in the present study appears to capture an important qualitative distinction among the 32 communities represented in our study sample.

From multilevel analyses where both individual and community characteristics were controlled, we found significant and positive associations between LHDhospital collaboration and the composite indices of risky behaviors $(\mathrm{OR}=1.18$; 95\% CI $=1.10-1.28$; Table 2$)$ and healthy nutrition/lifestyle behaviors $(\mathrm{OR}=1.12 ; 95 \% \mathrm{CI}=$ 1.05-1.19; Table 3). LHD-hospital collaboration was also significantly and positively associated with three individual outcomes: not smoking $(\mathrm{OR}=1.32,95 \% \mathrm{CI}=$ $1.11-1.58$; Table 2$)$, eating vegetables daily $(\mathrm{OR}=1.29$; 95\% CI $=1.06-1.57$; Table 3) and vigorous exercise $(\mathrm{OR}=1.17 ; 95 \% \mathrm{CI}=1.05-1.30$; Table 3$)$. In sensitivity analyses, removing the health insurance variable from the models did not materially change our findings.

In models that included the interaction term between LHD-hospital collaboration and social capital, we found a significant, positive interaction for two of our outcome measures: wearing a seatbelt ( $\mathrm{p}$ for interaction $=0.01$; Table 2) and general exercise ( $p$ for interaction $=0.03$; Table 3). After stratification, collaborative action was not significantly associated with either behavior. There were no interactions for other health behaviors or index variables (Tables 2 and 3).

\section{Discussion}

There is growing recognition that improving population health requires multi-sector collaboration. The Patient 
Table 1 Comparison of characteristics of individuals living in included vs. excluded communities in full BRFSS Smart cohort (total of 130 MMSAs)

\begin{tabular}{|c|c|c|}
\hline & $\begin{array}{l}\text { Included communities } \\
\text { ( } n=32 \text { MMSAs); } \\
\% \text { of all respondents }\end{array}$ & $\begin{array}{l}\text { Excluded communities } \\
(n=98 \mathrm{MMSAs}) ; \\
\% \text { of all respondents }\end{array}$ \\
\hline \multicolumn{3}{|l|}{ Sex } \\
\hline Male & 48.7 & 48.3 \\
\hline Female & 51.3 & 51.7 \\
\hline \multicolumn{3}{|l|}{ Marital } \\
\hline Married & 51.4 & 49.3 \\
\hline Divorced/Widowed/Separated & 19.9 & 19.2 \\
\hline Never Married & 23.6 & 25.6 \\
\hline Member unmarried couple & 4.4 & 5.1 \\
\hline Refused & 0.6 & 0.8 \\
\hline \multicolumn{3}{|l|}{ Education } \\
\hline Less than Grade 12 & 12.6 & 13.3 \\
\hline Grade 12 or GED (High school graduate) & 26.8 & 25.4 \\
\hline College 1 year to 3 years (Some college or technical school) & 32.0 & 30.0 \\
\hline College 4 years or more (College graduate) & 28.2 & 30.8 \\
\hline Refused & 0.4 & 0.5 \\
\hline \multicolumn{3}{|l|}{ Employment Status } \\
\hline Employed & 49.9 & 51.0 \\
\hline Not employed & 13.6 & 13.0 \\
\hline Retired & 29.2 & 28.8 \\
\hline Unable to work & 6.3 & 6.3 \\
\hline Refused & 1.0 & 0.9 \\
\hline \multicolumn{3}{|l|}{ Income } \\
\hline Less than $\$ 20,000$ & 12.3 & 13.3 \\
\hline$\$ 20,000$ to $\$ 75,000$ & 41.7 & 38.7 \\
\hline Greater than $\$ 75,000$ & 28.6 & 30.9 \\
\hline Refused/Don't know & 17.3 & 17.2 \\
\hline \multicolumn{3}{|l|}{ Preferred Race } \\
\hline White & 83.3 & 79.6 \\
\hline Black or African American & 8.1 & 11.1 \\
\hline Asian & 1.9 & 2.9 \\
\hline Other & 4.3 & 4.2 \\
\hline Refused/Don't know & 2.5 & 2.2 \\
\hline \multicolumn{3}{|l|}{ Age } \\
\hline Under 30 & 11.0 & 10.5 \\
\hline $30-50$ & 25.1 & 24.7 \\
\hline $50-65$ & 29.5 & 30.4 \\
\hline Over 65 & 33.1 & 33.0 \\
\hline Refused/Don't Know/Missing & 1.3 & 1.4 \\
\hline
\end{tabular}

Protection and Affordable Care Act of 2010 (ACA) encouraged nonprofit hospitals to collaborate with local public health experts in the conduct of CHNAs for the larger goal of improving community health [32]. Long- standing collaborations between the local public health and hospital sectors, however, appear to be quite limited $[10,11]$. A previous study using hospital IRS filings showed that only about half of nonprofit hospitals 
Table 2 Unstratified Odds Ratios of Individual-Level Risky Behaviors

\begin{tabular}{|c|c|c|c|c|c|c|c|c|c|c|}
\hline & \multicolumn{2}{|c|}{ Wearing a Seatbelt } & \multicolumn{2}{|c|}{ Not Smoking } & \multicolumn{2}{|c|}{ Not Binge Drinking } & \multicolumn{2}{|c|}{ Getting a Flu Shot } & \multicolumn{2}{|c|}{$\begin{array}{l}\text { Risky Behavior } \\
\text { Index }\end{array}$} \\
\hline & $\begin{array}{l}\text { Odds } \\
\text { Ratio }\end{array}$ & $95 \% \mathrm{Cl}$ & $\begin{array}{l}\text { Odds } \\
\text { Ratio }\end{array}$ & $95 \% \mathrm{Cl}$ & $\begin{array}{l}\text { Odds } \\
\text { Ratio }\end{array}$ & $95 \% \mathrm{Cl}$ & $\begin{array}{l}\text { Odds } \\
\text { Ratio }\end{array}$ & $95 \% \mathrm{Cl}$ & $\begin{array}{l}\text { Odds } \\
\text { Ratio }\end{array}$ & $95 \% \mathrm{Cl}$ \\
\hline \multicolumn{11}{|c|}{ Primary Predictors of Interest } \\
\hline Collaborative action & 1.55 & $\begin{array}{l}0.96 \\
2.49\end{array}$ & $1.32^{*}$ & $\begin{array}{l}1.11 \\
1.58\end{array}$ & 1.19 & $\begin{array}{l}0.92 \\
1.55\end{array}$ & 1.03 & $\begin{array}{l}0.89 \\
1.20\end{array}$ & $1.18^{*}$ & $\begin{array}{l}1.10 \\
1.28\end{array}$ \\
\hline Social capital index & 1.09 & $\begin{array}{l}0.67 \\
1.76\end{array}$ & 0.94 & $\begin{array}{l}0.80 \\
1.10\end{array}$ & 0.93 & $\begin{array}{l}0.75 \\
1.16\end{array}$ & $1.41^{*}$ & $\begin{array}{l}1.07 \\
1.87\end{array}$ & $1.15^{*}$ & $\begin{array}{l}1.05 \\
1.25\end{array}$ \\
\hline \multicolumn{11}{|l|}{ Individual-level Covariates } \\
\hline Male & $0.49^{*}$ & $\begin{array}{l}0.41 \\
0.58\end{array}$ & $0.63^{*}$ & $\begin{array}{l}0.48 \\
0.82\end{array}$ & $0.47^{*}$ & $\begin{array}{l}0.39 \\
0.57\end{array}$ & $0.79^{*}$ & $\begin{array}{l}0.69, \\
0.91\end{array}$ & $0.76^{*}$ & $\begin{array}{l}0.69 \\
0.83\end{array}$ \\
\hline Married & $1.48^{*}$ & $\begin{array}{l}1.12 \\
1.95\end{array}$ & $1.64^{*}$ & $\begin{array}{l}1.31 \\
2.05\end{array}$ & $1.35^{*}$ & $\begin{array}{l}1.00 \\
1.83\end{array}$ & $1.13^{*}$ & $\begin{array}{l}1.01 \\
1.27\end{array}$ & $1.23^{*}$ & $\begin{array}{l}1.09 \\
1.38\end{array}$ \\
\hline College & $1.37^{*}$ & $\begin{array}{l}1.09 \\
1.72\end{array}$ & $1.37^{*}$ & $\begin{array}{l}1.17 \\
1.61\end{array}$ & 0.94 & $\begin{array}{l}0.70 \\
1.24\end{array}$ & $1.25^{*}$ & $\begin{array}{l}1.07 \\
1.46\end{array}$ & $1.17^{*}$ & $\begin{array}{l}1.07 \\
1.27\end{array}$ \\
\hline Black & 0.86 & $\begin{array}{l}0.57 \\
1.30\end{array}$ & 1.02 & $\begin{array}{l}0.72 \\
1.42\end{array}$ & $1.45^{*}$ & $\begin{array}{l}1.06 \\
1.98\end{array}$ & $0.81^{*}$ & $\begin{array}{l}0.69 \\
0.95\end{array}$ & 0.89 & $\begin{array}{l}0.71 \\
1.12\end{array}$ \\
\hline Hispanic & 1.10 & $\begin{array}{l}0.76 \\
1.58\end{array}$ & $1.56^{*}$ & $\begin{array}{l}1.13 \\
2.15\end{array}$ & 1.16 & $\begin{array}{l}0.72 \\
1.87\end{array}$ & 0.87 & $\begin{array}{l}0.68 \\
1.11\end{array}$ & $0.90^{*}$ & $\begin{array}{l}0.85 \\
0.95\end{array}$ \\
\hline Asian & 1.05 & $\begin{array}{l}0.68 \\
1.64\end{array}$ & $3.10^{*}$ & $\begin{array}{l}1.05 \\
9.16\end{array}$ & $3.08^{*}$ & $\begin{array}{l}1.50 \\
6.32\end{array}$ & 1.10 & $\begin{array}{l}0.77 \\
1.55\end{array}$ & 1.04 & $\begin{array}{l}0.86 \\
1.25\end{array}$ \\
\hline Other Race & 1.05 & $\begin{array}{l}0.43 \\
2.57\end{array}$ & 0.99 & $\begin{array}{l}.042 \\
2.32\end{array}$ & 0.97 & $\begin{array}{l}0.49 \\
1.90\end{array}$ & 0.97 & $\begin{array}{l}0.48 \\
1.99\end{array}$ & 1.01 & $\begin{array}{l}0.76 \\
1.32\end{array}$ \\
\hline Age & $1.16^{*}$ & $\begin{array}{l}1.11 \\
1.22\end{array}$ & $1.09^{*}$ & $\begin{array}{l}1.01 \\
1.17\end{array}$ & $1.35^{*}$ & $\begin{array}{l}1.24 \\
1.48\end{array}$ & $1.36^{*}$ & $\begin{array}{l}1.29 \\
1.43\end{array}$ & $1.14^{*}$ & $\begin{array}{l}1.11 \\
1.17\end{array}$ \\
\hline Insured & 1.22 & $\begin{array}{l}0.75 \\
1.97\end{array}$ & $1.64^{*}$ & $\begin{array}{l}1.31 \\
2.04\end{array}$ & 1.06 & $\begin{array}{l}0.85 \\
1.31\end{array}$ & $1.98^{*}$ & $\begin{array}{l}1.46 \\
2.67\end{array}$ & $1.28^{*}$ & $\begin{array}{l}1.15 \\
1.43\end{array}$ \\
\hline Income $<\$ 15 k$ & 0.94 & $\begin{array}{l}0.47 \\
1.92\end{array}$ & $0.45^{*}$ & $\begin{array}{l}0.33 \\
0.62\end{array}$ & 1.19 & $\begin{array}{l}0.86 \\
1.65\end{array}$ & 0.88 & $\begin{array}{l}0.64 \\
1.21\end{array}$ & 0.93 & $\begin{array}{l}0.74 \\
1.17\end{array}$ \\
\hline Income \$15 k-75 k & 0.88 & $\begin{array}{l}0.66 \\
1.19\end{array}$ & $0.68^{*}$ & $\begin{array}{l}0.54 \\
0.86\end{array}$ & 1.13 & $\begin{array}{l}0.95 \\
1.36\end{array}$ & 0.93 & $\begin{array}{l}0.81 \\
1.07\end{array}$ & 0.97 & $\begin{array}{l}0.88 \\
1.06\end{array}$ \\
\hline \multicolumn{11}{|l|}{ Community-level Covariates } \\
\hline $\begin{array}{l}\text { Median household } \\
\text { income }\end{array}$ & 1.04 & $\begin{array}{l}0.93 \\
1.16\end{array}$ & 1.03 & $\begin{array}{l}0.97 \\
1.11\end{array}$ & 0.95 & $\begin{array}{l}0.90 \\
1.01\end{array}$ & 1.07 & $\begin{array}{l}0.96 \\
1.18\end{array}$ & 1.00 & $\begin{array}{l}0.97 \\
1.04\end{array}$ \\
\hline Percent Black & 1.03 & $\begin{array}{l}0.78 \\
1.36\end{array}$ & 0.93 & $\begin{array}{l}0.83 \\
1.04\end{array}$ & 0.98 & $\begin{array}{l}0.85 \\
1.12\end{array}$ & 0.91 & $\begin{array}{l}0.82 \\
1.02\end{array}$ & 0.98 & $\begin{array}{l}0.94 \\
1.02\end{array}$ \\
\hline Above Average FTEs & 0.99 & $\begin{array}{l}0.64 \\
1.55\end{array}$ & $1.30^{*}$ & $\begin{array}{l}1.09 \\
1.56\end{array}$ & 0.82 & $\begin{array}{l}0.61 \\
1.12\end{array}$ & 0.76 & $\begin{array}{l}0.56 \\
1.04\end{array}$ & 0.93 & $\begin{array}{l}0.81 \\
1.07\end{array}$ \\
\hline Local Board of Health & 0.71 & $\begin{array}{l}0.49 \\
1.02\end{array}$ & 0.92 & $\begin{array}{l}0.74 \\
1.13\end{array}$ & 1.11 & $\begin{array}{l}0.83 \\
1.65\end{array}$ & 0.90 & $\begin{array}{l}0.67 \\
1.23\end{array}$ & 0.92 & $\begin{array}{l}0.83 \\
1.01\end{array}$ \\
\hline \multicolumn{11}{|l|}{ State-level Covariates } \\
\hline Expanded Medicaid & 0.72 & $\begin{array}{l}0.49 \\
1.08\end{array}$ & 0.86 & $\begin{array}{l}0.74 \\
1.02\end{array}$ & $0.79^{*}$ & $\begin{array}{l}0.63 \\
0.98\end{array}$ & $0.78^{*}$ & $\begin{array}{l}0.67 \\
0.91\end{array}$ & $0.86^{*}$ & $\begin{array}{l}0.80 \\
0.93\end{array}$ \\
\hline$p$-value for interaction & 0.01 & & 0.46 & & 0.17 & & 0.88 & & 0.91 & \\
\hline
\end{tabular}

${ }^{*} P<0.05$. The social capital index was dichotomized into communities with an index above the median $(1=$ yes $)$ and below the median in our sample $(0=$ no). Individual-level covariates included being male, being married, graduating college, being Black, Asian, Hispanic, or Other race, having income in the specified range ( $<\$ 15,000$ /year, 15,000 to $75,000 /$ year), and having health insurance. The reference category for education was having less than a college degree and the reference for income was greater than $\$ 75,000$ per year. The remaining dichotomous predictors were coded as $1=$ yes; $0=$ no. The number of FTEs at the LHD was $=1$ if the LHD had more than the average FTEs in the Profile 2013 survey (mean $=65$ ). Community-level covariates included continuous measures of the population: percent black (Area Resource File, 2016; rescaled to a one-standard deviation change) and median household income (2014; rescaled to a \$10,000 unit change). A second model with an interaction term between collaborative action and social capital was also analyzed. The $p$-value for interaction is provided. 
Table 3 Unstratified Odds Ratios of Individual-Level Healthy Lifestyle Behaviors

\begin{tabular}{|c|c|c|c|c|c|c|c|c|c|c|c|c|}
\hline & \multicolumn{2}{|c|}{$\begin{array}{l}\text { Eating } \\
\text { Vegetables }\end{array}$} & \multicolumn{2}{|c|}{ Eating Fruit } & \multicolumn{2}{|c|}{ General Exercise } & \multicolumn{2}{|c|}{ Vigorous Exercise } & \multicolumn{2}{|c|}{ Healthy Weight } & \multicolumn{2}{|c|}{$\begin{array}{l}\text { Healthy Lifestyle } \\
\text { Index }\end{array}$} \\
\hline & $\begin{array}{l}\text { Odds } \\
\text { Ratio }\end{array}$ & $\begin{array}{l}95 \% \\
\mathrm{Cl}\end{array}$ & $\begin{array}{l}\text { Odds } \\
\text { Ratio }\end{array}$ & $\begin{array}{l}95 \% \\
\mathrm{Cl} \\
\end{array}$ & $\begin{array}{l}\text { Odds } \\
\text { Ratio }\end{array}$ & $\begin{array}{l}95 \% \\
\mathrm{Cl} \\
\end{array}$ & $\begin{array}{l}\text { Odds } \\
\text { Ratio }\end{array}$ & $\begin{array}{l}95 \% \\
\mathrm{Cl}\end{array}$ & $\begin{array}{l}\text { Odds } \\
\text { Ratio }\end{array}$ & $\begin{array}{l}95 \% \\
\mathrm{Cl}\end{array}$ & $\begin{array}{l}\text { Odds } \\
\text { Ratio }\end{array}$ & $\begin{array}{l}95 \% \\
\mathrm{Cl} \\
\end{array}$ \\
\hline \multicolumn{13}{|c|}{ Primary Predictors of Interest } \\
\hline Collaborative action & $1.29^{*}$ & $\begin{array}{l}1.06 \\
1.57\end{array}$ & 1.16 & $\begin{array}{l}0.99 \\
1.35\end{array}$ & 1.17 & $\begin{array}{l}1.00 \\
1.38\end{array}$ & $1.17^{*}$ & $\begin{array}{l}1.05 \\
1.30\end{array}$ & 1.06 & $\begin{array}{l}0.93 \\
1.21\end{array}$ & $1.12^{*}$ & $\begin{array}{l}1.05 \\
1.19\end{array}$ \\
\hline Social capital index & 1.10 & $\begin{array}{l}0.94 \\
1.29\end{array}$ & 1.11 & $\begin{array}{l}0.92 \\
1.33\end{array}$ & 0.91 & $\begin{array}{l}0.73 \\
1.13\end{array}$ & 1.05 & $\begin{array}{l}0.92, \\
1.19\end{array}$ & 0.95 & $\begin{array}{l}0.78 \\
1.17\end{array}$ & $1.07^{*}$ & $\begin{array}{l}1.01 \\
1.14\end{array}$ \\
\hline \multicolumn{13}{|l|}{ Individual-level Covariates } \\
\hline Male & $0.64^{*}$ & $\begin{array}{l}0.57 \\
0.72\end{array}$ & $0.71^{*}$ & $\begin{array}{l}0.58 \\
0.87\end{array}$ & 1.15 & $\begin{array}{l}0.99 \\
1.33\end{array}$ & 1.02 & $\begin{array}{l}0.92 \\
1.14\end{array}$ & $0.44^{*}$ & $\begin{array}{l}0.35 \\
0.57\end{array}$ & 0.96 & $\begin{array}{l}0.88 \\
1.06\end{array}$ \\
\hline Married & $1.35^{*}$ & $\begin{array}{l}1.09 \\
1.66\end{array}$ & $1.27^{*}$ & $\begin{array}{l}1.09 \\
1.48\end{array}$ & 1.18 & $\begin{array}{l}0.97 \\
1.45\end{array}$ & $1.31^{*}$ & $\begin{array}{l}1.07 \\
1.62\end{array}$ & $0.80^{*}$ & $\begin{array}{l}0.71 \\
0.90\end{array}$ & $1.12^{*}$ & $\begin{array}{l}1.03 \\
1.21\end{array}$ \\
\hline College & 1.16 & $\begin{array}{l}0.94 \\
1.42\end{array}$ & $1.16^{*}$ & $\begin{array}{l}1.08 \\
1.25\end{array}$ & 1.14 & $\begin{array}{l}0.90 \\
1.44\end{array}$ & $1.16^{*}$ & $\begin{array}{l}1.01 \\
1.34\end{array}$ & 1.15 & $\begin{array}{l}0.92 \\
1.43\end{array}$ & $1.11^{*}$ & $\begin{array}{l}1.05 \\
1.18\end{array}$ \\
\hline Black & $0.59^{*}$ & $\begin{array}{l}0.42 \\
0.82\end{array}$ & 1.17 & $\begin{array}{l}0.92 \\
1.49\end{array}$ & 0.69 & $\begin{array}{l}0.47 \\
1.00\end{array}$ & 0.97 & $\begin{array}{l}0.81 \\
1.18\end{array}$ & $0.52^{*}$ & $\begin{array}{l}0.35 \\
0.78\end{array}$ & 0.87 & $\begin{array}{l}0.74 \\
1.01\end{array}$ \\
\hline Hispanic & 1.13 & $\begin{array}{l}0.80 \\
1.60\end{array}$ & $1.25^{*}$ & $\begin{array}{l}1.07 \\
1.44\end{array}$ & $0.76^{*}$ & $\begin{array}{l}0.63 \\
0.92\end{array}$ & 0.91 & $\begin{array}{l}0.74 \\
1.13\end{array}$ & $0.59^{*}$ & $\begin{array}{l}0.52 \\
0.68\end{array}$ & $0.86^{*}$ & $\begin{array}{l}0.79 \\
0.94\end{array}$ \\
\hline Asian & 0.99 & $\begin{array}{l}0.72 \\
1.36\end{array}$ & 1.28 & $\begin{array}{l}0.86 \\
1.90\end{array}$ & 0.71 & $\begin{array}{l}0.49 \\
1.04\end{array}$ & 0.92 & $\begin{array}{l}0.68 \\
1.25\end{array}$ & $1.68^{*}$ & $\begin{array}{l}1.37 \\
2.07\end{array}$ & $0.82^{*}$ & $\begin{array}{l}0.75 \\
0.89\end{array}$ \\
\hline Other Race & 1.07 & $\begin{array}{l}0.57 \\
2.01\end{array}$ & 1.02 & $\begin{array}{l}0.66 \\
1.59\end{array}$ & 1.03 & $\begin{array}{l}0.51 \\
2.06\end{array}$ & 1.08 & $\begin{array}{l}0.48, \\
2.45\end{array}$ & 0.95 & $\begin{array}{l}0.43 \\
2.08\end{array}$ & 1.01 & $\begin{array}{l}0.81 \\
1.26\end{array}$ \\
\hline Age & 1.03 & $\begin{array}{l}0.98 \\
1.08\end{array}$ & $1.07^{*}$ & $\begin{array}{l}1.04 \\
1.11\end{array}$ & $0.85^{*}$ & $\begin{array}{l}0.82 \\
0.89\end{array}$ & $0.81^{*}$ & $\begin{array}{l}0.79 \\
0.83\end{array}$ & $0.81^{*}$ & $\begin{array}{l}0.77 \\
0.85\end{array}$ & 0.99 & $\begin{array}{l}0.96 \\
1.01\end{array}$ \\
\hline Insured & 1.05 & $\begin{array}{l}0.78 \\
1.41\end{array}$ & 1.08 & $\begin{array}{l}0.93 \\
1.26\end{array}$ & $1.46^{*}$ & $\begin{array}{l}1.03 \\
2.06\end{array}$ & $1.28^{*}$ & $\begin{array}{l}1.04 \\
1.57\end{array}$ & 1.02 & $\begin{array}{l}0.81 \\
1.30\end{array}$ & $1.11^{*}$ & $\begin{array}{l}1.03 \\
1.21\end{array}$ \\
\hline Income $<\$ 15 k$ & $0.54^{*}$ & $\begin{array}{l}0.34 \\
0.87\end{array}$ & $0.70^{*}$ & $\begin{array}{l}0.56 \\
0.88\end{array}$ & $0.49^{*}$ & $\begin{array}{l}0.37 \\
0.64\end{array}$ & $0.73^{*}$ & $\begin{array}{l}0.55 \\
0.96\end{array}$ & 0.92 & $\begin{array}{l}0.70 \\
1.22\end{array}$ & 0.93 & $\begin{array}{l}0.80 \\
1.09\end{array}$ \\
\hline Income \$15 k-75 k & $0.79^{*}$ & $\begin{array}{l}0.64 \\
0.99\end{array}$ & 0.91 & $\begin{array}{l}0.77 \\
1.08\end{array}$ & $0.72^{*}$ & $\begin{array}{l}0.62 \\
0.84\end{array}$ & $0.86^{*}$ & $\begin{array}{l}0.75 \\
0.98\end{array}$ & 0.98 & $\begin{array}{l}0.83 \\
1.17\end{array}$ & 0.97 & $\begin{array}{l}0.90 \\
1.03\end{array}$ \\
\hline \multicolumn{13}{|l|}{ Community-level Covariates } \\
\hline $\begin{array}{l}\text { Median household } \\
\text { income }\end{array}$ & $1.06^{*}$ & $\begin{array}{l}1.02 \\
1.10\end{array}$ & 1.06 & $\begin{array}{l}0.98 \\
1.14\end{array}$ & 1.02 & $\begin{array}{l}0.96 \\
1.08\end{array}$ & $1.05^{*}$ & $\begin{array}{l}1.01 \\
1.09\end{array}$ & 1.02 & $\begin{array}{l}0.95 \\
1.10\end{array}$ & 1.00 & $\begin{array}{l}0.98 \\
1.02\end{array}$ \\
\hline Percent Black & $0.89^{*}$ & $\begin{array}{l}0.82 \\
0.97\end{array}$ & $0.88^{*}$ & $\begin{array}{l}0.78 \\
1.00\end{array}$ & 0.94 & $\begin{array}{l}0.82 \\
1.08\end{array}$ & 1.01 & $\begin{array}{l}0.93 \\
1.11\end{array}$ & 0.99 & $\begin{array}{l}0.89 \\
1.10\end{array}$ & 0.99 & $\begin{array}{l}0.96 \\
1.03\end{array}$ \\
\hline Above Average FTEs & 0.97 & $\begin{array}{l}0.79 \\
1.18\end{array}$ & 1.18 & $\begin{array}{l}0.91 \\
1.52\end{array}$ & 0.99 & $\begin{array}{l}0.75 \\
1.31\end{array}$ & 0.91 & $\begin{array}{l}0.77 \\
1.07\end{array}$ & 1.08 & $\begin{array}{l}0.85 \\
1.38\end{array}$ & 1.01 & $\begin{array}{l}0.91 \\
1.11\end{array}$ \\
\hline Local Board of Health & $0.82^{*}$ & $\begin{array}{l}0.70 \\
0.95\end{array}$ & 0.912 & $\begin{array}{l}0.75 \\
1.14\end{array}$ & 0.99 & $\begin{array}{l}0.82 \\
1.19\end{array}$ & 0.97 & $\begin{array}{l}0.85 \\
1.10\end{array}$ & 1.04 & $\begin{array}{l}0.84 \\
1.27\end{array}$ & 0.96 & $\begin{array}{l}0.89 \\
1.03\end{array}$ \\
\hline \multicolumn{13}{|l|}{ State-level Covariates } \\
\hline Expanded Medicaid & $0.74^{*}$ & $\begin{array}{l}0.65 \\
0.85\end{array}$ & 1.10 & $\begin{array}{l}0.94 \\
1.29\end{array}$ & 0.92 & $\begin{array}{l}0.77 \\
1.10\end{array}$ & $0.82^{*}$ & $\begin{array}{l}0.73 \\
0.93\end{array}$ & 0.96 & $\begin{array}{l}0.85 \\
1.08\end{array}$ & 0.95 & $\begin{array}{l}0.90 \\
1.01\end{array}$ \\
\hline$p$-value for interaction & 0.23 & & 0.46 & & 0.03 & & 0.40 & & 0.14 & & 0.13 & \\
\hline
\end{tabular}

${ }^{*} \mathrm{P}<0.05$. The social capital index was dichotomized into communities with an index above the median $(1=$ yes $)$ and below the median in our sample $(0=$ no $)$ Individual-level covariates included being male, being married, graduating college, being Black, Asian, Hispanic, or Other race, having income in the specified range ( $<\$ 15,000$ /year, 15,000 to $75,000 /$ year), and having health insurance. The reference category for education was having less than a college degree and the reference for income was greater than $\$ 75,000$ per year. The remaining dichotomous predictors were coded as $1=$ yes; $0=$ no. The number of FTEs at the LHD was $=1$ if the LHD had more than the average FTEs in the Profile 2013 survey (mean $=65$ ). Community-level covariates included continuous measures of the population: percent black (Area Resource File, 2016; rescaled to a one-standard deviation change) and median household income (2014; rescaled to a \$10,000 unit change). A second model with an interaction term between collaborative action and social capital was also analyzed. The $p$-value for interaction is provided. 
reported including public health experts in any of their implementation activities [33]. Our findings are less optimistic in that $78 \%$ of the LHDs in this analysis reported low to no collaborative action on CHNA implementation with nonprofit hospitals in their community [33, 34].

We set out to study whether collaborative action between LHDs and nonprofit hospitals may impact community health. We found that after controlling for a number of other factors, LHD-hospital collaborative action was significantly associated with several healthy behaviors. Both of the composite health behavior indices showed significant positive associations, indicating that individuals living in communities with some level of LHD-hospital collaboration were more likely to report fewer risky behaviors and a greater number of healthy eating and exercising behaviors than those living in communities without documented long-standing collaborative action. Associations with all measured behaviors were in the hypothesized positive direction and three of these associations were both positive and significant. These findings are in line with the BARHII Framework's inclusion of strategic partnership at the institutional level. While the exact mechanism by which longstanding collaboration (i.e. alterations in the physical, social or service environment) may manifest its effects are unclear, these data show interesting potential impacts of such strategic collaboration.

For social capital, there was some evidence of moderation for two behaviors: wearing a seatbelt and general exercise. This is consistent with our hypothesis that community social capital resources may allow for a community to benefit from implementation activities put forth through LHD-nonprofit hospital collaborative action. From these data, we believe our inclusion of social capital to the BARHII Framework is warranted; however, further study of the mechanisms by which social capital can benefit collaborative action between hospitals and LHDs would be useful.

Although we report a positive association from LHDhospital collaborative action and individual-level healthy behaviors, only $22 \%$ of the communities represented by study respondents included an LHD that reported longstanding collaboration with nonprofit hospitals. While understanding why such collaboration is uncommon was not the objective of the current study, extant research points to several barriers. First, nonprofit hospitals may choose to focus on strategies that directly impact their current patient market instead of targeting the social and economic barriers to health of residents, especially those that do not receive health care at their institution. This choice minimizes the need to partner with external organizations, including the LHD. Second, funding for action (i.e., implementing programs) may be a concern to hospitals given the long-term nature of many strategies required to improve population health. From the LHD's perspective, budgets have been challenging, leaving staff to do more with less $[6,8]$. Third, while current regulations state that nonprofit hospitals must seek input from public health experts to analyze community needs, there is no such expectation for hospitals when prioritizing and implementing actions to meet those needs [9]. Without state or federal laws that require such efforts, nonprofit hospitals may see no rationale to include LHDs in executing implementation strategies.

\section{Strengths and limitations}

To our knowledge, this study offers the first analysis of long-standing collaborative action between LHDs and hospitals and individual-level health behaviors. Our study is exploratory yet methodologically robust in that we used multilevel models to explore impacts on individual-level behaviors, an advance over previous ecological studies. We believe we are also the first to assess whether social capital may play a role in modifying these relationships. We further focus on multiple modifiable health behaviors identified by the CDC as "winnable battles" that can be pivotal to substantially improving population health across the nation.

Nonetheless, there are several limitations to our study. First, our data was observational in nature, being mostly derived from surveys. While we accounted for community and individual-level covariates, it is possible that factors omitted from our multivariate models could contribute to residual confounding. Relatedly, as a crosssectional study, we could not rule out reverse causation; due to the emerging nature of this research, 2015 was the first, and only year of available data on collaborative action between LHDs and nonprofit hospitals on CHNA implementation from the perspective of the local health department. However, in line with our conceptual framework, we expect our measure of collaborative action to be indicative of a long-standing LHD-hospital collaboration that has developed over time in the communities studied [34]. Hence, the associations observed in this study represent collaborative relationships between hospitals and LHDs with subsequent community health that are not a direct result of regulation.

Second, because we relied on a single item assessment of long-standing collaboration, it was not possible to assess which specific strategies the LHD and hospital jointly implemented. Health behaviors we measured as outcomes may not directly relate to the actions being undertaken through collaborative action. A qualitative analysis of CHNA implementation reports would be useful to further unpack the elements and strategies of collaboration. 


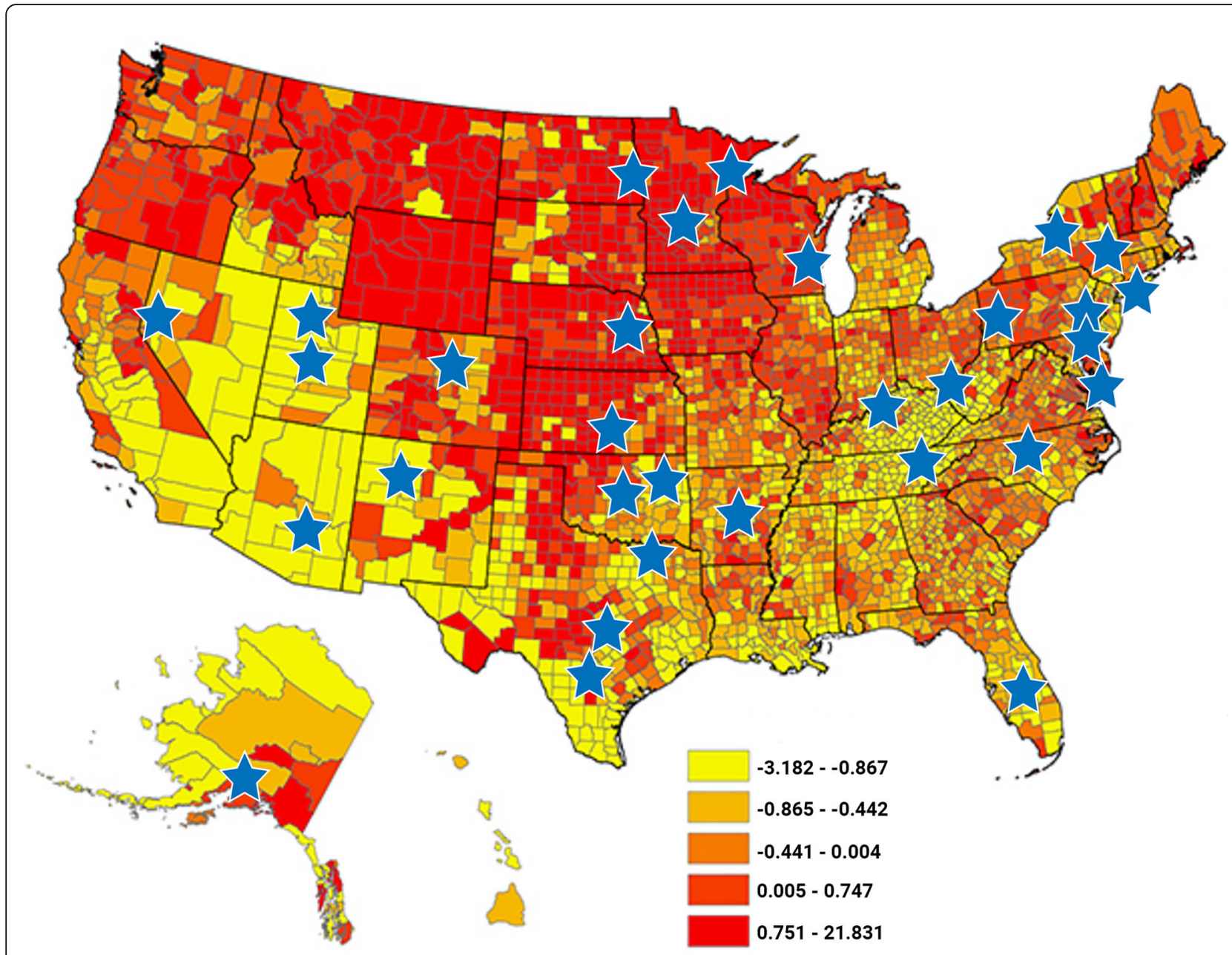

NE RCRD Copyright 2014, The Northeast Regional Center for Rural Development, all rights reserved.

Fig. 2 A Map of Included Communities and their Social Capital Index Values [35]. Permission was received to use and adapt the copyrighted image

Third, our measure of long-standing collaborative action captures the perspective of the LHD only and may not accurately reflect how hospitals in the community perceived the level of collaborative action on community health improvements activities with the LHD. Data from a prior study assessing collaboration with public health experts from the perspective of the nonprofit hospital showed similarly low levels of collaboration $[10,33]$.

Finally, while individuals from 25 of the 50 states were included in our sample, our study findings may not necessarily be generalizable to all communities in the US. Future studies that include individuals in the other 25 states would help to expand the external validity of our findings.

\section{Conclusions}

This study assessed whether collaborative action between local health departments and nonprofit hospitals was linked to individual-level self-reported health behaviors. Our findings show positive and significant associations for healthier behaviors (fewer risky behaviors and more healthy lifestyle behaviors). Additional research on collaborative action is needed including program evaluations that focus on health outcomes from specific 
population health initiatives involving the collaboration of local health departments and hospitals. However, given that many LHDs still do not report any collaborative action with nonprofit hospitals in their area, research is also needed to better understand the barriers to such collaboration. Should our findings be replicated in future work including program evaluations and observational longitudinal studies, they may serve to encourage policy makers to consider incentives for LHDs and hospitals to take collaborative action to impact the health of their communities.

\section{Abbreviations}

ACA: Affordable Care Act; BARHII: Bay Area Regional Health Inequities Initiative; BRFSS: Behavioral Risk Factor Surveillance Survey; CDC: Centers for Disease Control; CHNA: Community Health Needs Assessment;

Cl: Confidence Interval; FTE: Full-Time Equivalents; IHI: Institute for Healthcare Improvement; LHD: Local Health Department; MMSA: Metropolitan and Micropolitan Statistical Area; NACCHO: National Association of County and City Health Officials; NRCRD: Northeast Regional Center for Rural Development at Penn State; OMB: Office of Management and Budget; OR: Odds Ratio

\section{Acknowledgements}

We thank John Griffith, PhD for biostatistical support.

\section{Authors' contributions}

GRC conceived and designed the project, acquired and analyzed the data, interpreted data and drafted the manuscript. GJY assisted in the conception and design, interpretation of the data, assisted in drafting manuscript and provided substantive revisions. SS acquired and interpreted data and provided substantive revisions to the manuscript. JM provided substantive revisions to the manuscript. DK assisted in the conception and design of the project and interpretation of the data, provided substantive revisions to the manuscript, and supervised the study. All authors have read and approved the manuscript.

\section{Funding}

No funding was provided for this research.

\section{Availability of data and materials}

Data used in this study came from:

https://www.cdc.gov/brfss/smart/smart_2015.html (publicly available). https://aese.psu.edu/nercrd/community/social-capital-resources/social-capitalvariables-for-2014 (publicly available).

http://nacchoprofilestudy.org/forces-of-change/2015-forces-of-change/ (not publicly available)

http://nacchoprofilestudy.org/data-requests/ (not publicly available). https://www.hilltopinstitute.org/our-work/hospital-community-benefit/ hospital-community-benefit-state-law-profiles/ (publicly available). https://data.census.gov/cedsci/table?d=ACS\%205-Year\%20Estimates\%2 0Data\%20Profiles\&table=DP02\&tid=ACSDP5Y2015.DP02 (publicly available).

\section{Ethics approval and consent to participate}

This study was reviewed and approved by the Northeastern University IRB.

\section{Consent for publication}

Not applicable.

\section{Competing interests}

GRC declares no competing interests. GJY declares no competing interests. SS declares no competing interests. JM declares no competing interests. DK declares no competing interests.

\section{Author details}

'Bouvé College of Health Sciences and the Center for Health Policy and Healthcare Research, Northeastern University, Boston, MA, USA. ${ }^{2}$ Bouvé College of Health Sciences, D'Amore-McKim School of Business and the Center for Health Policy Healthcare Research, Northeastern University, Boston, MA, USA. ${ }^{3}$ Department of Health Management and Policy, University of Michigan, Ann Arbor, USA. ${ }^{4}$ Bouvé College of Health Sciences, Northeastern University, Boston, MA, USA. ${ }^{5}$ Bouvé College of Health Sciences and the School of Public Policy and Urban Affairs, Northeastern University, Boston, MA, USA.

Received: 22 July 2020 Accepted: 4 December 2020

Published online: 02 January 2021

\section{References}

1. Davis K, Stremikis, K, Schoen, C, Squires, D. Mirror, Mirror on the Wall, 2014 Update: How the U.S. Health Care System Compares Internationally. Commonwealth Fund. 2014. Available at: https://www.commonwealthfund. org/publications/fund-reports/2014/jun/mirror-mirror-wall-2014-updatehow-us-health-care-system. Accessed on May 18, 2020.

2. National Research Council and Institute of Medicine. U.S. Health in International Perspective: Shorter Lives, Poorer Health. Panel on Understanding Cross-National Health Differences Among High-Income Countries. Washington, DC: The National Academies Press; 2013.

3. Dwyer-Lindgren L, Bertozzi-Villa A, Stubbs RW, et al. Inequalities in life expectancy among US counties, 1980 to 2014: temporal trends and key drivers. JAMA. 2017;177(7):1003-11. https://doi.org/10.1001/jamainternmed. 2017.0918.

4. Robert Wood Johnson Foundation. Culture of health. 2015. Available at: https://www.rwjf.org/en/cultureofhealth.html. Accessed on May 18, 2020.

5. University of Wisconsin Population Health Institute. County Health Rankings Key Findings 2018. 2018. Available at: https://www.countyhealthrankings. org/resources/2018-county-health-rankings-key-findings-report. Accessed on May 18, 2020.

6. Jacobson P, Parment W. Public health and health care: integration, disintegration or eclipse. J Law Med Ethics. 2018;46:940-51. https://doi.org/ 10.1177/1073110518821994.

7. Benton K, Polite, S. The disconnect between public health and health care. Vol march-April. Catholic health Association of the United States; 2016. Available at: www.chausa.org. Accessed on May 18, 2020.

8. Trust for America's Health. The Impact of Chronic Underfunding of America's Public Health System: Trends, Risks, and Recommendations, 2019. 2019. Available at: https://www.tfah.org/report-details/2019-funding-report/. Accessed on: May 18, 2020.

9. United States Government. An Act Entitled The Patient Protection and Affordable Care Act. In: Department of Health and Human Services, ed. Obama Care Act. Washington, D.C.: U.S. G.P.O.; 2010.

10. Beatty KE, Wilson KD, Ciecior A, Stringer L. Collaboration among Missouri nonprofit hospitals and local health departments: content analysis of community health needs assessments. Am J Public Health. 2015;105(Suppl 2):S337-44. https://doi.org/10.2105/ajph.2014.302488.

11. Pennel CL, McLeroy KR, Burdine JN, Matarrita-Cascante D. Nonprofit hospitals' approach to community health needs assessment. Am J Public Health. 2015;105(3):e103-13. https://doi.org/10.2105/ajph.2014.302286.

12. Mays GP, Mamaril CB, Timsina LR. Preventable death rates fell where communities expanded population health activities through multisector networks. Health Aff (Project Hope). 2016;35(11):2005-13. https://doi.org/10. 1377/hlthaff.2016.0848.

13. Bay Area Regional Health Inequities Initiative (BARHII). A Public Health Framework for Reducing Health Inequities. 2015; http://barhii.org/ framework/. Accessed August 3, 2018.

14. Tranel M, Gasen K. Community Partnerships: A Sustainable Resource for Nongovernmental Organizations. Federal Reserve Bank; 2003.

15. Mattessich P, Monsey B. Community building: what makes it work. St. Paul: Amherst H. Wilder Foundation; 1997.

16. Putnam RD. Bowling alone: the collapse and revival of American community. New York: Simon \& Schuster; 2000.

17. Austin JE, Seitanidi MM. Collaborative value creation: a review of partnering between nonprofits and businesses: part I. value creation Spectrum and collaboration stages. Nonprofit Volunt Sect Q Title. 2012:41(5):726-58. https://doi.org/10.1177/0899764012450777. 
18. Centers for Disease Control and Prevention. 2015 SMART: BRFSS City and County Data and Documentation 2015; https://www.cdc.gov/brfss/smart/ smart_2015.html.

19. Providence Alaska Medical Center. Anchorage Community Health Needs Assessment. 2015. Available at: https:/www.psjhealth.org/-/media/files/ providence-st-joseph-health/community-benefit/ak/2015 chnaandchipprovidencealaskamedicalcenter.pdf?la=en. Published: 2015.

20. UPMC Mercy. Community Health Needs Assessment and Community Health Strategic Plan. Available at: https://www.upmc.com/-/media/upmc/ about/community-commitment/documents/mercy-community-healthneeds-assessment.pdf. Published: June 30, 2013.

21. National Association of County and City Health Officials (NACCHO). About. 2019; https:/www.naccho.org/about. Accessed June 10, 2019.

22. National Association of County and City Health Officials. Forces of Change Survey. 2015. http://nacchoprofilestudy.org/forces-of-change/2015-forces-ofchange/.

23. Carlton EL, Singh SR. Joint community health needs assessments as a path for coordinating community-wide health improvement efforts between hospitals and local health departments. Am J Public Health. 2018;108(5): 676-82. https://doi.org/10.2105/AJPH.2018.304339.

24. Prybil LD, Scutchfield FD, Dixon RE. The Evolution of Public Health-Hospital Collaboration in the United States. Public Health Rep. 2016;131(4):522-5.

25. Rupasingha A, Goetz SJ, Freshwater D. The production of social capital in US counties. J Soc Econ Res. 2006;35(1):83-101. https://doi.org/10.1016/j. socec.2005.11.001.

26. United States Government. Area Health Resource File. Department of Health and Human Services HRSA, 2015. https://data.hrsa.gov/topics/healthworkforce/ahrf.

27. United States Government. Census Data. 2015. https://www.census.gov/en. html.

28. Hilltop Institute. Community benefit state law profiles. Baltimore: University of Maryland; 2013. https://hilltopinstitute.org/our-work/hospital-communitybenefit/hcbp-state-comparison/.

29. Schenck AP, Meyer AM, Kuo T, Cilenti D. Building the evidence for decisionmaking: the relationship between local public health capacity and community mortality. Am J Public Health. 2015;105(S2):S211-6.

30. Chaudhary KR, Schreiber-Gregory DN. Multiple Imputation for Arbitrary Missing Data: SAS and R. Available at: https://www.mwsug.org/ proceedings/2015/TT/MWSUG-2015-TT-04.pdf. Published: 2015.

31. Ene ML, Blue EA, Bell BA, et al. Multilevel models for categorical data using SAS ${ }^{\otimes}$ PROC GLIMMIX: the basics. 2014.

32. United States Government. Schedule H (Form 990). In: Service IR, ed; 2014 Available at: https://support.sas.com/resources/papers/proceedings15/343 0-2015.pdf. Published: 2014.

33. Rosen Cramer G, Singh SR, Flaherty S, Young GJ. The Progress of US hospitals in addressing community health needs. Am J Public Health. 2017; 107(2):255-61. https://doi.org/10.2105/ajph.2016.303570.

34. Singh S, Carlton E. Local health departments' involvement in hospitals implementation plans. Front Public Health Serv Sys Re. 2016;5(4):34-9.

35. Northeast Center for Rural Development. County-level measure of social capital. 2018. Available at: https://aese.psu.edu/nercrd/community/socialcapital-resources. Accessed April 28, 2018

\section{Publisher's Note}

Springer Nature remains neutral with regard to jurisdictional claims in published maps and institutional affiliations.

Ready to submit your research? Choose BMC and benefit from:

- fast, convenient online submission

- thorough peer review by experienced researchers in your field

- rapid publication on acceptance

- support for research data, including large and complex data types

- gold Open Access which fosters wider collaboration and increased citations

- maximum visibility for your research: over $100 \mathrm{M}$ website views per year

At BMC, research is always in progress.

Learn more biomedcentral.com/submissions 